\title{
Hunters and Gatherers of the Rio Grande Plain and the Lower Coast of Texas
}

Thomas R. Hester

Center for Archaeological Research

Follow this and additional works at: https://scholarworks.sfasu.edu/ita

Part of the American Material Culture Commons, Archaeological Anthropology Commons, Environmental Studies Commons, Other American Studies Commons, Other Arts and Humanities Commons, Other History of Art, Architecture, and Archaeology Commons, and the United States History Commons

Tell us how this article helped you.

This Article is brought to you for free and open access by the Center for Regional Heritage Research at SFA ScholarWorks. It has been accepted for inclusion in Index of Texas Archaeology: Open Access Gray Literature from the Lone Star State by an authorized editor of SFA ScholarWorks. For more information, please contact cdsscholarworks@sfasu.edu. 


\section{Hunters and Gatherers of the Rio Grande Plain and the Lower Coast of Texas \\ Creative Commons License \\ (c) () () (9)}

This work is licensed under a Creative Commons Attribution-NonCommercial 4.0 International License 
HUNTERS AND GATHERERS OF THE RIO GRANDE PLAIN AND THE LOWER COAST OF TEXAS

Thomas R. Hester

Center for Archaeological Research The University of Texas at San Antonio Non-Serial Publication, No. 1

1976

Second Printing 1977 


\section{HUNTERS AND GATHERERS OF THE RIO GRANDE PLAIN AND THE LOWER COAST OF TEXAS}

Thomas R. Hester

Center for Archaeological Research The University of Texas at San Antonio Non-Serial Publication, No. 1

1976

Second Printing 1977 


\section{PREFACE}

This paper was presented at a symposium entitled "Archaeology in Texas", held on March 12, 1971, during the annual meeting of the Texas Academy of Science, at Nacogdoches, Texas.

Many sections of the paper are now outdated in light of archaeological work in southern Texas over the past five years. However, because of the numerous requests for copies of the paper, and its utility in introducing students and amateur archaeologists to the region's prehistory, the Center for Archaeological Research is making it available in mimeographed form, only sightiy revised from the original 1971 version.

\section{INTRODUCTION}

In this brief paper, I will attempt to summarize prehistoric cultural manifestations found on the Rio Grande Plain of Texas. A portion of this paper is devoted to a discussion of past and present environments, as I feel that a knowledge of these is essential to an understanding of prehistoric life in the area. The scanty data now available on the regional culture sequence are presented. However, my primary goal in this paper is to briefly outline the major prehistoric cultural traditions on the Rio Grande Plain. These traditions represent ecological adaptive responses made by the prehistoric inhabitants, and are reflected in the archaeology and ethnology of the area.

At the time of European contact, the Rio Grande Plain was occupied by hunting and gathering peoples of the Coahuiltecan linguistic stock. All evidence suggests that it was their ancestors who Tived in this region for most, if not al1, of the prehistoric era.

Archaeological work has been sporadic in the region, with most activity occurring within the past 10 years. Some small areas are now known in some detail, but vast portions rema in to be studied. Syntheses of the area have been presented by Sayles (1935), Suhm, Krieger, and Jelks (1954), Kelley (1959), Campbe11 (1960), and Hester (1969a). I will reserve a discussion of the history of archaeological research in the region for a later version of this paper.

\section{CONTEMPORARY PHYSIOGRAPHY AND ENVIRONMENT}

Wildlife ecologists (cf. Ingl is 1964) have used the term "Rio Grande Plain" to describe the southern part of Texas, bordered on the west by the Rio Grande, on the east and south by the Gulf of Mexico, and on the north by the Edwards Plateau and the San Antonio River. As a physiographic unit, it is included within the West Gulf Coastal Plain (Fenneman 1937), with elevations varying from sea 
level along the coast to 1000 feet in the interior. The topography is one of rolling hills and plains. Major drainage systems of the region center on the
Rio Grande and Nueces Rivers.

The Rio Grande Plain conforms closely to the geographic extent of the Tamaulipan Biotic Province (B1air 1950). In general, the interior is a mesquite and desert grass savanna ( $c f$. Kroeber 1939), characterized by two major ecological zones: (1) the uplands, which are rather open and have a plant community dominated by mesquite and other thorn bush, native grasses, and prickly pear; (2) the floodplains of the rivers and their major tributaries; these are often infested with mesquite, but have forested areas of oak, ash, elm, hackberry, and pecan in riparian zones along the stream courses. The coastal portion of the Rio Grande Plain is a prairie grassland, with mesquite and motts of live oak (Johnston 1963).

The regional fauna are also characteristic of the Tamaulipan Biotic Province. Common species include whitetail deer, peccary, jackrabbits, cottontail rabbits, coyote, a variety of avifauna, including turkey, hawk, and quail, and reptilian species such as land turtle, iizards, and snakes. The fauna have been detailed in papers by W. Frank Blair (1950, 1952).

Thornthwaite (1948) has described the contemporary climate as semiarid and megatherma T. However, Russe11 (1945) recognizes two major climatic divisions on the Rio Grande Plain. He describes the interior as an area of mesothermal steppe climate, with the dry season occurring in winter. The coastal area is - also classed as mesothermal, but has occasional tropical or desert years and has adequate precipitation in all seasons. In general, both areas have hot and humid summers and mild winters.

\section{PREHISTORIC ENVIRONMENT}

My discussion of the prehistoric environment is based on accounts of Spanish explorers during the early post-contact period (see Inglis 1964 for a summary) and on climatic sequences developed for adjacent central and TransPecos Texas (Bryant and Larson 1968; Bryant 1970). There have been dramatic shifts in vegetational and faunal pattens in the historic era and these will be briefly mentioned below.

Middle and Late Pleistocene environments on the Rio Grande Plain may have resembled those of central Texas, described by Bryant (1970) as "parkland." The occurrence of mastodon and mammoth remains in southern Texas suggest that both grasslands (ideal habitat for mammoth) and forest elements (forage for mastodons) were present (Lundelius 1967: 297). In post-Pleistocene times, the climate was one of gradually increasing aridity, as shown in pollen sequences from adjacent areas. Based on an examination of available environmental data, I think we can safely conceive of the post-Pleistocene environment on the Rio Grande Plain as one with temperatures similar to today, but with the vegetation that of a grassland steppe or savanna. There were some clusters of trees on the uplands, but most woody vegetation was in riparian zones along the streams. The two major ecological zones seen in the area today were probabiy present in the prehistoric period.

The savanna conditions of prehistoric times have been altered by the invasion 
of thorn brush, particularly mesquite, in the last 300 or 400 years (Bogusch 1952; Harris 1966). These thorny invaders came to dominate the region by the late j9th century. Plant geographers differ on the causes of such brush invasion, but several factors are evidently responsible. It is most likely that resident populations of mesquite were present in the prehistoric riparian zones. Their spread over the uplands in the historic period was aided by the introduction of livestock ranching and the overgrazing which followed, and possibly the cessation of aboriginal burning of the savannas (cf. Covey 1961; Harris 1966; C. 0. Sauer, personal communication). Harris (1966) believes short-term climatic fluctuations may have also figured in the spread of the thorny brush.

The fauna were similar to those of today, though habitats have no doubt been altered by historic farming and ranching practices. Notabiy absent from contemporary fauna, but present in the early postcontact and prehistoric periods, are bison, antelope, and bear. Bison may have been restricted to the northern fringes of the region and to areas along the coast, but antelope were widely distributed (Inglis 1964) and are excellent indicators of the former savanna conditions.

It is also evident from early Spanish and Anglo records that surface water was much more abundant in prehistoric times. Numerous creeks were perennial and springs were common. Many creeks and springs were still active into the early 20 th century, but have since gone dry because of lowered water tables resulting from watershed destruction and deep-well irrigation.

\section{PREHISTORIC CULTURE SEQUENCE}

We can only briefly consider the culture sequence for the Rio Grande Plain, as most parts of the sequence rema in poorly defined. I have summarized many of the extant data in previous papers (Hester 1969a; Hester, White, and White 1969). The prehistoric occupations can be separated into three generalized time periods: Paleo-Indian, Archaic, and Late Prehistoric.

The earliest datable remains are represented by fluted points of the clovis and Folsom types. These styles are widely scattered throughout the region. The greatest concentrations of Clovis points are found in the northern part of the Rio Grande Plain. Folsom specimens share the same general distribution pattern, though more examples of this type are present in the south. Both types occur along the coast. Since sea levels were lower in Late Pleistocene times, these early occupations may have extended some distance onto the now-inundated continental sheif. There are numerous examples of mastodon and mammoth on the Rio Grande Plain. It may be that both species of proboscideans were extinct by the time man arrived in the area, but as of the present none of these numerous skeletal finds have been firmly dated. Sellards' (1940) investigations in the Berclair terrace near the coast revealed early point styles in apparent association with a variety of extinct fauna. Some students of Paleo-Indian prehistory (cf. Wormington 1957) believe these associations to be the result of secondary deposition. However, there appear to have been intact flint-working areas and other occupational refuse in close proximity to these disputed associations. It is difficult to explain why thse intact features were not disturbed by the same depositional processes which supposedly affected the points and fauna.

Two possible associations of artifacts and mammoth remains are known from 
the Falcon Reservoir on the lower Rio Grande (Cason 1952; Suhm, Krieger, and Jelks 1954). At a site on 0so Creek near Corpus Christi, a very large mineralized bone point reminiscent of those from Llano Complex kili-sites (cf. Sellards
1952; Haynes 1966) was found among eroded elephant remains.

The latter part of the Paleo-Indian period is marked by numerous lanceolate and stemmed dart points, including classic Plainview, Plainview Golondrina, Angostura, Meserve, Milnesand, Lerma, and Scottsbluff (Weir 1956; Hester 1968a, 1968b, 1969a; Hester and Hi11 1971a). These are placed in a late Paleo-Indian status based on correlations with dated examples from adjacent areas (cf. MacNeish 1958; Alexander 1963; Sorrow 1968). Since many of these forms have been found with Archaic debris on eroded sites, there is a possibility that they survived later in the region (cf. Hester 1968b). At a site on the Guadalupe River near Victoria, large bifacial Clear Fork gouges, and possible Plainview points, are eroding out of alluvium at depth of 13 feet. Studies in northeastern Mexico by J. F. Epstein (1969) have pointed out the early origins of the clear Fork tool form.

Our data are much too meager to allow speculation on Paleo-Indian 1ifeways. Conclusive evidence for the hunting of megafauna is absent. It is most 1ikely that the Paleo-Indian occupation of the area was characterized by smal1 roaming groups of non-specialized hunters and gatherers (Newton 1968).

The Archaic of the Rio Grande Plain is, at present, a morass. Only in the - Falcon Reservoir has a living floor of the period been recognized (Hartle and Stephenson 1951). It contained a variety of triangular and subtriangular dart points, Clear Fork gouges, and other bifacial and unifacial tools, and was dated to 2700 B.C. (Krieger 1954). However, these data tell us nothing about earlier or later phases in the Archaic sequence. The great similarities between artifact forms on the Rio Grande Plain and those of adjacent northeastern Mexico suggest possible cultural relationships. It may well be that the Archaic cultural sequence in southern Texas closely parallels the developments seen by MacNeish (1958) for northern Tamaulipas. His Nogales, Repelo, Abasolo, and Catan complexes represent an Archaic continuum without significant alterations in the cultural. inventory. In short, the Archaic in both areas is probably characterized by the use of similar tool forms for many thousands of years. For example, Nance (1970) has Tortugas points at 1200 B.C. in Nuevo Leon, and we know they were present in the Falcon Reservoir about 2700 B.C. Clear Fork gouges appeared in late Paleo-Indian times and were still present in Late Archaic and Late Prehistoric occupations. In the study of the Rio Grande Plain Archaic, I think we should avoid the use of concepts like the Falcon and Meir foci, neither of which have been substantiated, and we should avoid the formulation of unfounded projectile point sequences such as one recentiy proposed by Newton (1968).

Perhaps the best defined temporal unit in the region is the Late Prehistoric period. It begins with the introduction of several new traits into the cultural inventory, particularly the bow and arrow and ceramics. These manifestations probably date to around 1200 A.D. (Hester 1971d). This period is well-represented on the littoral by the Rockport Complex (Campbe11 1960), with a variety of arrow point styles and asphalt-painted sandy paste pottery, and the Brownsville Complex (MacNeish 1947, 1958), with a shell industry, triangular arrow points, and possibly ceramics. In the interior, no complexes are currently defined. Perdiz, Scallorn, Fresno, and other arrow point styles occur throughout the area, along with plain bone-tempered pottery (Hester 1968c; Hester and Hill 1971b). Recent excavations 
and controlled collections have shown that small so-called dart points in the area are associated with arrow point forms and probably had the same function (Hill and Hester 1971; Hester 1970a). Several discrete Late Prehtstorlc components are known (Nunley and Hester 1966; Hester and Parker 1970; Hill and Hester 1971). In addition to arrow points and ceramics, the cultural inventory includes we 17 -made flake end scrapers, perforators made on flakes, and laterally-retouched blades. (For a more recent study, see T. R. Hester and T. C. Hill, Jr., "Some Aspects of Late Prehistoric and Protohistoric Archaeology in Southern Texas", University of Texas at San Antonio, Center for Archaeological Research, Special Report 1, 1975).

The historic era in southern Texas began with Cabeza de Vaca ca. 1528 (Krieger 1961). The native populations were either eradicated or assimilated into Spanish-Mexican groups. The period saw occasional intrusions by Lipan Apache and Comanche. Metal arrow points and trade beads are sometimes found (Nunley and Hester 1966; Hester 1970b).

\section{POST-PLEISTOCENE ADAPTATIONS}

I believe that the most productive line of research into the prehistoric human occupation of this region lies in the study of the cultural adaptations made by the peoples. We have so few data on the Paleo-Indian period that I will restrict the present discussion to the post-Pleistocene occupations. For the time being, we must operate under the assumption that the post-pleistocene climatic conditions were similar to those described earlier in the paper. As a result of the environmental conditions, it is my postulate that two major ecological adaptations were made, both of which are reflected in the archaeological and ethnographic records. One adaptational tradition was concentrated in the interior savanna and is thus termed the "savanna adaptation." The other is found along the lower coast. It represents a tradition geared to the exploitation of marine resources and is called the "maritime adaptation." Both traditions are briefly described in this paper. These two adaptations were not the only ones developed by Coahuiltecan peoples. The arid areas of northeastern Mexico saw a desert adaptation (Taylor 1966; Varner 1968; Epstein 1969). In the Laguna district of western Coahuila, there may have been a lake-side or lacustrine adaptation (Martinez del Rio 1954; Davila Aguirre 1967).

I feel that we can obtain the best view of the two Rio Grande Plain adaptations by an examination of prehistoric settlement and subsistence patterns. In this study, I follow the definition of K. C. Chang (1958) in considering the settlement pattern to be the manner in which human settlements are arranged over the landscape in relation to the physiographic environment.

\section{The Savanna Adaptation}

Archaeological research in the interior of the Rio Grande Plain has consisted largely of surface collecting. Problem-oriented studies are few. Some preliminary statements on settlement and subsistence activities have been given by Newton (1968), Shiner (1969), and Hester (1970d). In this paper, I wi11 confine the discussion of the savanna adaptation to an intensively-studied area in northwestern Zavala County. This area lies well within the interior savanna and should reflect the savanna adaptation as it occurs over much of the interior. With additional research in the savanna, we can expect to refine these data and secure information on regional variations. 
The study area in northwestern Zavala County is one of low topographic relief. There are several large creeks, all tributaries of the Nueces River. They have dendritic drainage patterns and broad floodplains. I11-defined low terraces are present, and natural levees are found along the stream banks. The stream valleys are rimmed by high gravel terraces and broad sandy uplands.

Site types in the study area show a very definite physiographic distribution pattern. Most sites occur on the floodplains. These are living sites or villages, situated either on natural levees paralleling the stream courses or in open flats out on the floodplain. The riparian habitat along the streams is thickly vegetated, yet the sites on the levees and flats are usually open. Site size varies considerably. In the study area, sites on the natural levees are up to 200 meters long and 60 or more meters in width. These large sites probably represent preferred camping spots used as base camps by groups during subsistence rounds. Several natural levee sites have been test-excavated in the study area, revealing an abundance of cultural remains buried in homogeneous alluvium over one meter in thickness. Included in these midden accumulations are finished artifacts of various kinds, lithic waste, lumps of baked clay, burned rocks, mussel and snail shells, and charcoal. The nature of these deposits indicate that day-to-day occupation was concentrated in these floodplain sites, and most manufacturing and processing activities were conducted there. Future horizontal exposure of these floodpla in sites should reveal much data on the spatial ordering of these communities. Surface observations have already provided some information on intrasite structure. Controlled surface collecting has shown that discrete biface manufacturing areas are present at two floodplain sites. Other collecting activities have led me to believe that areas of tool concentration can be expected at many sites and may provide clues to manufacturing or processing activities. Hearths are commoniy found, though they do not appear to be restricted in their distribution at these living sites. They are oval in outline and made of sandstone; al1 appear to have been built on the ground surface. At one site, an ash-filled pit was found. Concentrations of mussel and snail shells occur, probabiy representing meal refuse. A mano cache was found at one site. Though burials were not found at floodplain sites in the study area, they are occasionally found in such contexts elsewhere in the savanna region (Hester 1969b).

Other types of sites occur on high gravel terraces rimming the stream valleys. Most common are chipping stations, with large amounts of flake refuse, partial1y-worked cores, and broken preforms. The debitage from these sites reveal the presence of at least two major flint-working industries in the savanna. One is based on the manufacture and subsequent modification of flakes, and the other on the bifacing of cobbles (Hester 1971c). There are also sma11, short-term campsites, probably subsidiaries of living sites on the floodplains. These may have been used during hunting or food-collecting. It should be noted that occasional living sites of large size occur on gravel terraces, especially when the terraces extend near the stream course. The presence of Paleo-Indtan projectile points in some of these terrace sites suggest that they might have been the preferred living areas during that period.

Upland sites within the Zavala County study area are usually quite smal1 in area, and consist of one or two scattered hearths and some associated lithic debris. Such sites no doubt represent very temporary campsites, perhaps occupied by hunters or foragers away from the floodpla in base camps. It should be pointed out, however, that larger occupation sites are sometimes found in the uplands. These usually occur on high hills far from present-day water sources. 
It is possible that such sites were situated near now-dry springs.

We must take much of our knowledge of savanna subsistence patterns from the ethnographic accounts of Ruecking $(1953,1955)$, Troike (1962), and Newcomb (1961). We know that the resident populations were hunters and foragers, living in small exogamous patrilocal microbands. Their subsistence pattern can be characterized as a seasonal round during which these smal1 groups ranged through territory regarded as their own, stopping at preferred campsites for a few weeks while partially (though not totaliy) exploiting the surrounding countryside (Ruecking 1953). As with most non-agricultural groups, seasonal plant food harvests were quite important. For example, Coahuiltecan groups from many areas of the savanna would come together during pecan nut harvests in the fall, and prickly pear fruit and mesquite bean harvests in the spring and summer (Ke11y 1952). Details on many of the Coahuiltecan subsistence activities can be obtained from Ruecking $(1953,1955)$ and Krieger (1956).

Let us look briefly at the archaeological evidence of the savanna subsistence regime.* Faunal remains from living sites are dominated by bones of the whitetail deer. Remains of jackrabbit and cottontail rabbit are present, and bones of the land turtle are common. Thus far, bison bones are scarce, suggesting that bison herds may have been rare intruders into the area. Bones of turkey and other unidentified avifauna occur. Riverine resources were no doubt heavily used, but fish remains are very rare (bones of the alligator gar have been found at one site). Freshwater mussels occur in great abundance at most sites. In some areas of the savanna, as on the Mexican side of the Rio Grande below Eagle Pass and on the Frio River in McMulien County, mussels appear to have been quite heavily exploited (Hester 1969e; Wakefield 1968). The land snail must have been the object of much foraging endeavor as their shel1s are found in quantity at the living sites. Ethnographic accounts indicate that the gathering of plant foods from riparian, terrace, and upland resource areas was paramount in savanna subsistence activities. Of course, remains of these vegetal items are not preserved. Manos and metates do occur at living sites, and some of the manos are stained, perhaps from contact with plant foods. Plant foods were stored in pits and were used over much of the year (cf. Espinosa, in Weddle 1968).

The floodplain living sites were obviously the base camps during the seasonal subsistence rounds. They were situated in a rich riparian microenvironment and were located close to reliable water sources. From these camps, small parties of hunters and foragers could go out into the terrace and upland resource areas. Additional research may tell us many of the food items exploited in the various resource areas. The tool kit used in the savanna included both stemed and unstemmed projectile points and a great variety of unifacial and bifacial tools. Most common of the tool forms are triangular unifaces and bifaces known as Clear Fork gouges (Hester, Gilbow, and Albee 1973). Their

* Recent analyses of faunal remains from late Prehistoric sites in Zavala County reveal the occurrence of a number of antelope; other species include deer, bison, rabbits, coyote, raccoon, gray fox, numerous rodents, and reptiles. See T. R. Hester and T. C. Hi11, Jr., "Some Aspects of Late Prehistoric and Protohistoric Archaeology in Southern Texas", University of Texas at San Antonio, Center for Archaeological Research Special Report 1. 1975. 
wide distribution suggests that they had some utilitarian processing function. Wear is often found in the form of nibbling and edge dulling. Edge angle values range between $45^{0}-75^{0}$ for which Wilmsen (1968) has inferred a varjety of uses, including hide-working and plant-fiber shredding. Large thin bifaces are included in the tool kit. Many of these could represent preforms, but many show dulling and other wear indicative of their use as knives (cf. Hester 1970e). Many of the scraper forms were probably hafted. At the Morhiss site in Victoria County, a number of bifacial tools retain traces of asphaltum used in hafting. Scrapers hafted with sinew or with gum are known from western Coahuila and similar hafting techniques were probably used on the Rio Grande Plain. We should not overlook the importance that baskets, nets, traps, and wooden tools played in the prehistoric tool kit (Ruecking 1953).

\section{The Maritime Adaptation}

The prehistoric peoples of the lower Texas coast were of the same linguistic stock as those of the interior, and their cultures were similar in many respects. However, these coastal peoples early developed an adaptational tradition oriented toward marine resources. This portion of the Texas coast is characterized by broad sandy prairies and shallow estuary systems. We can briefly consider the settlement patterns as known from two study areas. In Kleberg County, numerous living sites are found along the fringes of Baffin and Grul 1o Bays (Hester 1969c, 1971a). These are Tiving sites confined largely to the bay edge and located atop clay dunes (for a description of clay dunes, consult Price 1958). Clay dunes are ideal for occupation as they are elevated and we11-drained, and most importantly, have freshwater ponds adjacent on the inland side. A few small living sites are found on the inland prairie around playas and freshwater ponds.

The living sites on the clay dunes are usually heavily eroded, with vast exposures of marine she11s, snail she11s, and burned clay lumps. Some intact hearths were recorded, and were formed by oval arrangements of fired clay lumps which served as surrogate hearthstones in this stoneless environment (Hester $1971 a, 1971 b)$. In some sites, there appear to be restricted hearth areas. Burial areas occur at a few sites, and at least two discrete cemetery sites are known (Hester 1969d).

Subsistence-related remains at the living sites are numerous. Land fauna include whitetail deer, land turtle, and possibly oppossum. Most abundant are the remains of fish, shellfish, and crustaceans obtained from bay resource areas; of the fish, the Black Drum was most popular (Hester 1971a). Oyster was a favored food item obtained from the bays, though the ecology has so changed that it no longer lives there. Some Gulf shell species are present. Though remains of migratory waterfowl have not been found on the sites, they were numerous in the area and ethnographic accounts indicate that they were hunted (Gatschet 1891). The prairies probably were exploited for plant foods, especially prickly pear tunas (see Krieger 1956).

Similar subsistence and settlement data are available from the Oso Creek vicinity below Corpus Christi (Hester, ms.). About 40 sites are known along the creek; most are living sites and clay dunes. Four cemetery sites are also known (Hester 1969b). One site had several hundred interments, $70 \%$ of which were buried in a characterisic flexed position. Burial goods sometimes occur 
at these sites; the presence of discrete burial sites and consistent interment patterns suggest the presence of a prehistoric mortuary complex in this area. Faunal and molluscan remains are similar to those from the Baffin and Grullo Bays area. At the Kirchmeyer site, bones of deer, bison, and fish were found. At that site, excavations revealed clusters of deer bone, one of which was in a small pit, and concentrations of snail shells. Zones of snail shells can be seen at other 0so Creek sites.

I will just briefly mention another maritime adaptation, as seen in the Brownsville Complex at the mouth of the Rio Grande. We know little about settlement or subsistence patterns, though they appear to be similar to those just described. Cemetery sites are also present (Collins, Hester, and Weir 1969 ; Hester and Ruecking 1969; Hester 1969b). There was a she 11 industry developed in the Brownsville Complex; ornaments from it were traded widely, into the Huastecan and into western Coahuila (Hester 1969b). In return for the shel1, the Brownsville peoples received ornaments of jadeite, pieces of obsidian, and ceramic vessels. An extensive trading network was probably also present in the Baffin and 0so areas. Both Krieger (1956) and Schaedel (1949) comment that coastal peoples traded she 11 tools and ornaments to savanna peoples in return for hides, deer hair tassels, and flint. Evidence of this trade is known from the savanna (Hester 1970c).

The maritime tool kit reflects the adaptations made by the coastal peoples. Tools are most commonly of shell and include scrapers, gouges, adzes, picks, and hammers. Projectile points were made of shell and stone. Most of the flint tools, including unifaces and bifaces, were quite small and were resharpened repeated1y, reflecting the scarcity of flint (Shafer and Hester 1971; Hester 1971a). The desire for more efficient use of the imported flint resources may have been the stimulus which led to the development of a core-blade industry in late Prehistoric times. The blades obtained in this new technology were retouched for use as cutting tools (Hester and Shafer 1975).

\section{SUMMARY}

This paper has provided a general summary of the prehistory of the Rio Grande Plain and lower coast of Texas, and the following brief concluding statements are offered:

(1) It seems likely that savanna conditions existed on much of the Rio Grande Plain in post-Pleistocene times. The brush-infested conditions of today are the result of relatively-recent biotic and human factors. Much paleoecological research is needed to define the exact nature of the postPleistocene environment both in the interior and on the littoral.

(2) The prehistoric culture sequence of the Rio Grande Plain is sketchily known. There is ample evidence of occupation throughout the Paleo-Indian period, and some hints of man-megafauna associations. The Archaic occupations probabiy represent a continuum with few changes in artifact styles through time. The appearance of arrow points, bone-tempered ceramics, and some new tool forms mark the Late Prehistoric period.

(3) The archaeological and ethnohistorical evidence suggests the presence of two major human adaptive traditions on the Rio Grande Plain. One developed in response to savanna conditions in the interior, while the other was oriented toward the maritime conditions of the lower Texas coast. Examination of settle- 
ment and subsistence patterns, as well as the prehistoric tool kit, reflect these adaptations. There is great need for chronological control in the region in order to trace the development of these adaptations.

(4) I think that we should not think of the aboriginal cultures of the Rio Grande Plain as existing in some sort of cultural backwash or "sink." Instead, the data suggest that they were sufficiently adapted to making a living in their environment. This efficiency may be reflected in the continuum of artifact forms. New traits were not taken up except under unusual circumstances, such as the introduction of the bow and arrow and ceramics in Late Prehistoric times (cf. Coe and Flannery 1967).

\section{REFERENCES CITED}

Abbreviations Used

$\begin{array}{ll}\text { A Ant } & \text { American Antiquity } \\ \text { BTAS } & \text { Bulletin, Texas Archeological Society } \\ \text { P-TASP } & \text { Papers, Texas Archeological Salvage Project } \\ \text { PA } & \text { Plains Anthropologist } \\ \text { TJS } & \text { Texas Journal of Science }\end{array}$

ATexander, H. L. Jr.

1963 The Levi Site: A Paleo-Indian Campsite in Central Texas. A Ant, Vol. 28, No. 4: 510-527.

Blair, W. F.

1950 The Biotic Provinces of Texas. TJS, Vol. 2, No. 1: 93-117.

1952 Mammals of the Tamaulipan Biotic Province in Texas. TJS, Vol. 4, No. 2: $230-250$.

Bogusch, E. R.

1952 Brush Invasion in the Rio Grande Plain of Texas. TJS, Vor. 4, No. 1: 85-91.

Bryant, V. M.

1970 General Comment. Radiocarbon, Vol. 12, No. 2: 625.

Bryant, V. M. and D. A. Larson

1968 Pollen Analysis of the Devil's Mouth Site, Val Verde County, Texas. P-TASP, No. 14: 57-70.

Campbe11, T. N.

1960 Archeology of the Central and South Sections of the Texas Coast. BTAS, Vo1. 29: 145-176.

Cason, J. F.

1952 Report on Archaeological Salvage in Falcon Reservoir, Season of 1952. BTAS, Vol. 23: 218-259. 
Chang, K. C.

1958 Study of the Neolithic Social Grouping: Examples from the New World. American Anthropologist, Vol. 60: 298-334.

Coe, M. D. and K. V. Flannery

1967 Early Cultures and Human Ecology in South Coastal Guatemala: Smith. Contr. to Anthropology, Vol. 3 (whole vol.).

Collins, M. B., T. R. Hester and F. A. Weir

1969 The Floyd Morris Site (41 CF 2). BTAS, Vol. 40: 119-146.

Coviey, C. (ed.)

1961 Cabeza de Vaca's Adventures in the Unknown Interior of America. Collier, N. Y.

Davila Aguirre, J. de J.

1967 Chichicamet1. University of Coahuila, Saltillo.

Epstein, J. F.

1969 The San Isidro Site. University of Texas, Anthropology Papers, No. 7 .

Fenneman, N. M.

1931 Physiography of Eastern United States. McGraw-Hi11, N. Y.

Gatschet, A. S.

1891 The Karankawa Indians. Peabody Museum, Vol. 1, No. 2.

Harris, D. R.

1966 Recent Plant Invasions in the Arid and Semiarid Southwest of the United States. Annals, Assoc. Amer. Geogr., Vol. 56: 408-422.

Hartle, D. D. and R. L. Stephenson

1951 . Archaeological Investigations at the Falcon Reservoir, Starr County, Texas. Mimeo., River Basins Survey.

Haynes, C. V.

1966 Elephant Hunting in North America. Scientific American, Vol. 214, No. 6: 104-112. 
Hester, T. R.

1968a Folsom Points from Southwest Texas. PA, Vo1. 13, No. 40: 117.

1968b Paleo-Indian Artifacts from Sites Along San Miguel Creek. BTAS, Vol. 39: 147-161.

1968c Notes on Pottery-Bearing Sites in Southern Texas. But1-Roarer, Vol. 3, No. 2: 9-11.

1969a An Introduction to the Archaeology of Southern Texas. Annual Meeting, Society for American Archaeology, Milwaukee.

1969b The Floyd Morris and Ayala Sites: Discussion and Comparison. BTAS, Vol. 40: 157-166.

1969c Archeological Investigations in Kenedy and Kleberg Counties, Texas, in August, 1967. Texas State B1dg. Commission, Archeological Program, Report No. 15.

1969d Human Bone Artifacts from Southern Texas. A Ant, Vo1. 34, No. 3: 326-328.

1969e Notes on South Texas Archaeology: Sites Along the Middle Frio River Drainage. The Record, Vo1. 25, No. 4: 25-31.

1970a An Interim Statement on Archaeological Research at Chaparrosa Ranch Texas. Report submitted to the Texas State Historical Survey Committee, Austin.

1970b Metal Projectile Points from Southern Texas. The Record, Vol. 27: $9-11$.

1970c Marine Shells from Archaeological Sites in Southwest Texas. TJS, Vol. 22: 87-88.

1970d An Initial Study of Subsistence-Settlement Patterns of Prehistoric Hunters and Gatherers on the Texas Coastal Plain. Meeting of Southwestern Anthropol. Assoc. and Soc. for California Archaeol. As ilomar.

1970e A Study of Wear Patterns on Hafted and Unhafted Bifaces from Two Nevada Caves. University of California Archaeo1. Res. Fac., Contributions No. 7: 44-54.

1971a Loyola Beach: An Example of Aboriginal Adaptation to the Maritime Environment of the Lower Texas Coast. Florida Anthropologist, Vol. 24: 91-106.

$1971 \mathrm{~b}$ Notes on Baked Clay Objects from the Texas Coast. Notebook. University of South Carolina Inst. of Archaeol, and Anthropol. Vol. 3, No. 1: 15-17. 
1971c Chipped Stone Industries on the Rio Grande Plain of Texas. TJS (appeared in 1975; Vol, 26, Nos, 1-2: 213-222).

1971d Archeological Investigations at the La Jita Site. Uvalde County, Texas. BTAS, Vol. 42: 51-148.

ms. Notes on the Archaeology of 0so Creek, Lower Texas Coast. Ms. in preparation.

Hester, T. R., D. Gilbow and A. Albee

1973 A Functional Analysis of "Clear Fork" Artifacts from the Rio Grande Plain, Texas. A Ant, Vo1. 38, No. 1: 90-96.

Hester, T. R. and T. C. Hill, Jr.

1971a Notes on Scottsbluff Points from Southern Texas. Southwestern Lore, Vol. 37, No. 1: 27-33.

1971b An Initial Study of a Prehistoric Ceramic Tradition in Southern Texas. PA, Vol. 16, No. 52: 195-203.

Hester, T. R. and R. Parker

1970 The Berclair Site: A Late Prehistoric Component in Goliad County, Southern Texas. BTAS, Vol. 41: 1-24.

Hester, T. R. and F. Ruecking

1969 The Ayala Site. BTAS, Vol. 40: 147-157.

Hester, T. R. and H. J. Shafer

1975 An Initial Study of Blade Technology on the Central and Southern Coast. PA 20(69): 175-185.

Hester, T. R., L. D. White and J. White

1969 Archeological Materials from the Oulline Site and other Sites in LaSalle County, Texas. TJS, Vol. 21 , No. 2 : 130-165.

Hi11, T. C., Jr. and T. R. Hester

1971 Isolated Late Prehistoric and Archaic Components at the Honeymoon Site, Southern Texas. PA, Vol. 15, No. 54: 52-59.

Inglis, J. M.

1964 A History of Vegetation on the Rio Grande Plain: Texas Parks and Wildlife Bulletin, No. 45. 
Johnston, M. C.

1963 Past and Present Grassiands of Southern Texas and Northeast Mexico. Ecology, Vol. 44, No. 3: 456-466.

Kelley, J. C.

1952 Some Geographic and Cultural Factors Involved in Mexican-Southeastern Contacts. 29th Int. Cong. Americanists: 139-144.

1959 The Desert Cultures and the Balcones Phase: Archaic Manifestations in the Southwest and Texas. A Ant, Vo1. 24, No. 3: 276-288.

Krieger, A. D.

1954 A Radiocarbon Date on the Falcon Focus. BTAS, Vo1. 25: 565.

1956 Food Habits of the Texas Coastal Indians in the Ear1y 16th Century. BTAS, Vol. 27: 47-58.

1961 The Travels of A7var Nuñez Cabeza de Vaca in Texas and Mexico, 1534-1536. Homenaje a Pablo M. del Rio: 459-474.

Kroeber, A. L.

1939. Cultural and Natural Areas of Native North America. University of California Publ. Amer. Archaeol. \& Ethnol., Vol 38.

Lundelius, E. L., Jr.

1967 Late-Pleistocene and Holocene Faunal History of Central Texas. Pleistocene Extinctions ( $P$. Martin and H. Wright, Jr., eds.): 287-320. New Haven.

MacNeish, R. S.

1947 A Preliminary Report on Coastal Tamautipas. A Ant, Vol. 13. No. 1: $1-15$.

1958 Preliminary Archaeological Investigations in the Sierra de Tamaulipas, Mexico. Trans., Amer. Philosophical Soc., Vol. 48: 1-209.

Martinez del Rio, P.

1954 La Comarca Lagunera a fine de1 Siglo XVI a principios del XVII Segun las Fuentes Escritas. Inst. de Hist. de la Univ. Naciona 1 , Mexico.

Nance, R.

1970 General Comments. Radiocarbon, Vol. 12, No. 2: 638-639.

Newcomb, W. W., Jr.

1961 The Indians of Texas: University of Texas Press, Austin. 
Newton, M. B., Jr.

1968 The Distribution and Character of Sites, Arroyo Los 01mos, Starr County, Texas. BTAS, Vol. 38: 18-24.

Nunley, J. P. and T. R. Hester

1966 Preliminary Archeological Investigations in Dimmit County, Texas. TJS, Vol. 18, No. 3: 233-253.

Price, W. A.

1958 Sedimentology and Quaternary Geomorphology of South Texas.

Corpus Christi Geol. Soc. Field Trip Manua 1: 41-75.

Ruecking, F., Jr.

1953 The Economic System of the Coahuiltecan Indians of Southern Texas and Northeast Mexico. TJS, Vol. 5, Mo. 4: 480-497.

1955 The Coahuiltecan Indians of Southern Texás and Northeast Mexico. Russel1, R. J. MA thesis, University of Texas, Austin.

1945 Climates of Texas. Annals, Association of American Geographers, Vol. 35: 37-52.

Sayles, E. B.

1935 An Archaeological Survey of Texas. Medal1ion Papers, No. 16.

Schaedel, R. P.

1949 Karankawa Indians of the Texas Coast. Southwestern Journal of Anthropology, Vol. 5: 117-137.

Sellards, E. H.

1940 P1eistocene Artifacts and Associated Fossits from Bee County, Texas. Bulletin, Geol. Society of America, Vol. 51: 1627-1657.

1952 Earily Man In America. University of Texas Press, Austin.

Shafer, J. H. and T. R: Hester

1971 A Technological Study of Certain Bifacial Tools from Southern Texas. Archeological Report, Texas State Historical Survey Committee, No. 20.

Shiner, J. L.

1969 Component Analysis for Archaic Sites. BTAS, Vol. 41: 215-230. 
Sorrow, W. M.

1968 . The Devil's Mouth Site; The Third Season. P-TASP, No. 14.

Suhm, D. A., A. D. Krieger and E. B. Jelks

1954 An Introductory Handbook of Texas Archeology. BTAS, Vol. 25.

Taylor, W. W.

1966 Archaic Cultures Adjacent to the Northeastern Frontiers of MesoAmerica. Handbook of Middle American Indians, Vo 1. 4: 59-94.

Thornthwaite, C. W.

1948 An Approach Toward a Rational Classification of Climate. Geographical Review, Vo1. 38: 55-94.

Troike, R. C.

1962 Notes on Coahuiltecan Ethnography. BTAS, Vol . 32: 57-64.

Varner, D. M.

1968 The Nature of Non-Buried Archeology Data: Problems in Northeastern Mexico. BTAS, Vo1. 38: 51-65.

Wakefield, W.

1968 Archeological Surveys of Palmetto Bend and Choke Canyon Reservoirs, Texas. Survey Report No. 5, TASP

Weddle, R. S.

1968 San Juan Bautista: Gateway to Spanish Texas. University of Texas Press, Austin.

Weir, F. A.

1956 Surface Artifacts from La Perdida, Starr County, Texas. BTAS, Vol. $27:$ 59-78.

Wilmsen, E. N.

1968 Functional Analysis of Flaked Stone Artifacts. A Ant, Vol. 33, No. 2: 156-161.

Wormington, H. M.

1957 Ancient Man in North America. 4th Edition. Denver Museum of Natural History, Popular Series No. 4. 